\title{
OXT Gene Product
}

National Cancer Institute

\section{Source}

National Cancer Institute. OXT Gene Product. NCI Thesaurus. Code C128463.

A protein encoded by the OXT gene. 